\title{
Proxy-based 300-year High Arctic climate warming record from Svalbard
}

\author{
Luoto, Tomi P.
}

2019-05

Luoto , T P , Ojala , A E K \& Zajaczkowski , M 2019 , ' Proxy-based 300-year High Arctic

climate warming record from Svalbard ' , Polar Record , vol. 55 , no. 3 , pp. 132-141 . https://doi.org/10.1017/S00322

http://hdl.handle.net/10138/312442

https://doi.org/10.1017/S0032247419000275

cc_by_nc_nd

acceptedVersion

Downloaded from Helda, University of Helsinki institutional repository.

This is an electronic reprint of the original article.

This reprint may differ from the original in pagination and typographic detail.

Please cite the original version. 


\section{Abstract}

2

3 We used fossil Chironomidae assemblages and the transfer function approach to reconstruct summer air temperatures over the past 300 years from a High Arctic lake in Hornsund, Svalbard. Our aims were to compare reconstructed summer temperatures with observed (last 100 years) seasonal temperatures, to determine a potential climate warming breakpoint in the temperature series and to assess the significance and rate of the climate warming trend at the study site. The reconstructed temperatures were consistent with a previous proxy record from Svalbard and showed good correlation with the meteorological observations from Bjørnøya and Longyearbyen. From the current paleoclimate record, we found a significant climate warming threshold in the 1930s, after which the temperatures rapidly increased. We also found that the climate warming trend was strong and statistically significant. Compared to the reconstructed Little Ice Age temperatures in late $18^{\text {th }}$ century cooling culmination, the present day summer temperatures are $>4{ }^{\circ} \mathrm{C}$ higher and the temperature increase since the $1930 \mathrm{~s}$ has been $0.5^{\circ} \mathrm{C}$ per decade. These results highlight the exceptionally rapid recent warming of southern Svalbard and add invaluable information on the seasonality of High Arctic climate change and Arctic amplification.

Keywords: Arctic amplification; Chironomidae; Climate change; Paleoclimatology; Paleolimnology; Temperature

\section{(1)}




\section{Introduction}

Although the Arctic plays a globally significant role in the ongoing climate change, the long-term climate patterns have been challenging to establish, especially in the High Arctic. The homogenized Svalbard Airport (Longyearbyen) temperature record is one of the rare long-term instrumental temperature series from the High Arctic (Nordli et al., 2010), but its early part (1912-1920) may be less reliable due to series combination from different sources (Kohler et al., 2002). Because of scarcity of long instrumental records from the High Arctic, proxy-based indirect reconstructions are needed to interpret Arctic trends in terms of past long-term climate oscillations. This long-term information is crucial for thorough understanding of natural climate dynamics and ongoing and future trends in Arctic climate change from local to regional scales.

In addition to ice core records (Klein et al., 2016; Lecavalier et al., 2017), lake sediment archives are the most useful proxy sources for paleotemperature reconstructions (Besonen et al., 2008; Kaufman, 2009). From the variety of different lake sediment paleolimnological temperature proxies, fossil chironomids (Insecta: Diptera: Chironomidae) have proven most useful for reconstructions of Arctic climate change for several reasons (Thomas et al., 2008; Axford et al., 2009; Nazarova et al., 2017). Most chironomids have aquatic larval stage, which leave behind wellpreserved chitinous head capsules (Hofmann, 1988). Since chironomids are regularly encountered even in the coldest lakes and they are highly sensitive to temperature, with each taxa having a specific temperature preference (Eggermont \& Heiri, 2012; Engels et al., 2014), taxonomical analysis of chironomid head capsules readily provides information on prevailing climate conditions at each chronologically dated interval of a sediment downcore profile. By combining biostratigraphical analysis with available chironomid-based temperature training sets (calibrationin-space) it is possible to provide quantitative estimates of paleotemperature. In fact, chironomidbased temperature models for the Arctic areas have become more available nowadays with a pan- 
Arctic coverage (Self et al., 2011; Fortin et al., 2015; Nazarova et al., 2015). In this transfer function approach, multivariate statistical models, such as those based on weighted-averaging and partial least squares techniques, relate modern communities (surface sediment assemblages from multiple lakes) to environmental conditions (e.g. temperature) that can be further applied to fossil assemblages from deeper sediment layers and reconstructions of past environmental changes (Shala et al., 2017; Plikk et al., 2019).

As the Arctic has a large influence on global climate system, the paleoclimate reconstructions in the Arctic provide a basis to understand longer-term climate trends and to assess the consequences of threshold changes in regional climate system and their dynamics. During the recent decades, most profound warming in the Arctic, including Svalbard (Førland et al., 2011), has taken place during winter. Moreover, paleoclimate evidence, which is strongly focused on summer conditions, shows that Arctic summers are now warmer than at any time during at least the last Millennium (Werner et al., 2018). It has also been shown that changes in the length of the ice-free season have triggered a set of interlinked feedbacks that will amplify future rates of summer warming (Chapin et al., 2005).

In this study, we use a fossil chironomid biostratigraphy and apply a regional calibration model to quantitatively reconstruct mean July air temperatures from a 300-year-long High Arctic lake sediment profile derived from Revvatnet in Hornsund, southern Svalbard. We test the reconstructed values of the last 100 years against available meteorological data with special interest on differences between summer and annual temperatures. The aims of the study include determining a potential breakpoint for climate warming in southern Svalbard and to assess the significance of possible climate warming trend. We also estimate the rate of climate warming in the study area, which is of high significance since Svalbard is located in the climatically particularly sensitive region at an intersection of Arctic and Atlantic oceanic water-masses where the Polar Front develops (Isaksson et al., 2007; Majewski et al., 2009). Research carried out in the recent 
decades show that in the European Arctic, the air temperature increase during the Medieval Warm Period (MWP) and Modern Warming (MW) correlate with the strong influence of the warm Atlantic Water (Wanamaker et al., 2012). In turn, the weakening of the Atlantic Meridional Overturning Circulation and lower heat transport to the Arctic might be responsible for the Little Ice Age (LIA) cooling (Lund et al., 2006). At present, the climate/oceanographic conditions in the west Spitsbergen fjords are shaped mainly by the inflow of warm and highly saline Atlantic waters transported from the south by West Spitsbergen Current (Nilsen at al., 2016). Therefore, considering the unique ocean-atmosphere interplay of the study area, disentangling detailed features of long-term development in the climate of southern Svalbard is invaluable to understand past, present and future large-scale Arctic climate processes, feedback mechanisms and land-oceanatmosphere interactions.

\section{Material and methods}

\section{Study site}

Revvatnet $\left(77.022^{\circ} \mathrm{N}, 15.368^{\circ} \mathrm{E} ; 30 \mathrm{~m}\right.$ a.s.1.) is an oligotrophic lake located near the Hornsund fjord, southern Svalbard (Fig. 1a). The lake has a surface area of $0.9 \mathrm{~km}^{2}$ and a maximum depth of $26 \mathrm{~m}$ (Fig. 1b). The measured epilimnetic pH of the lake was 7.6 in June 2013. The average modern July air temperature is $4.8^{\circ} \mathrm{C}$ (Cisek et al., 2017) with daily temperatures generally varying between 3 and $10{ }^{\circ} \mathrm{C}$ at the Hornsund meteorological station (Norwegian Meteorological Institute) located 4 $\mathrm{km}$ southeast from Revvatnet at the Polish Polar Station Hornsund. An approximately $2{ }^{\circ} \mathrm{C}$ increase in summer air temperature has been instrumentally observed since the initiation of measurements in 1979 (Marsz \& Styszyńska, 2013). The catchment of Lake Revvatnet is characterized by periglacial tundra with outwash plains, ancient marine terraces, talus and proluvial cones, and undulating 
ground moraine that appear all around the Hornsund Bay and on the hills of adjacent mountains (Ojala et al., 2016). There are several side hanging valleys with active glaciers near Revvatnet, such as Eimfjellbreane, Gangsbreen, and Skålfjellbreen, but no geomorphological evidence exists that would suggests glaciers advancing and covering the entire Revvatnet basin during the Late Holocene. However, the hydrology of the basin is governed by the discharge of surface runoff waters via creeks into the basin from the north, which at least partly originates from valley glaciers.

\section{Sediment samples and chironomid analysis}

A 30-cm sediment profile RE2 sampled with a Kajak corer in June 2013 was used in the present study. The core was taken from a water depth of $23.5 \mathrm{~m}$ (Fig. 1b) as part of a larger lake survey. Further details on sampling can be found from a previous publication (Ojala et al., 2016). ${ }^{137} \mathrm{Cs}$ analysis was used to indicate an age horizon for the atmospheric nuclear weapons testing maximum fallout that occurred in $1963 \mathrm{CE}$ (Fig. 2). The ${ }^{137}$ Cs analysis was performed using an EGandG Ortec ACE TM-2 K gamma spectrometer equipped with a four-inch NaI/TI detector at the Geological Survey of Finland. The age horizon of the RE2 core was verified by ${ }^{137} \mathrm{Cs}$ analysis of other cores from the lake (RE1, RE3 and RE4).

$$
\text { Results of fossil chironomid community analysis are previously published in a }
$$
multiproxy paper focusing on long-term ecological shifts, biogeochemical cycling and microplastic accumulation in Revvatnet (Luoto et al., 2019). In brief, standard methods were used for chironomid analysis and a minimum head capsule counting sum per sample was set to 50 (Brooks et al., 2007). The most common chironomid taxa ( $\geq 2$ occurrences) are given in Fig. 3 .

\section{Numerical methods}


For temperature reconstruction, we used a chironomid-based temperature training set constructed on basis of several North Scandinavian datasets (Luoto, 2009; Luoto et al., 2014, 2016; Luoto \& Ojala, 2017) and here further updated it with 10 additional High Arctic sites mostly from the Hornsund area and Nordaustlandet. The mean July air temperature gradient of the model is $1.8-17.1{ }^{\circ} \mathrm{C}$. As the model type, locally weighted-weighted average (LWWA) regression with squared chi-squared distance as the dissimilarity coefficient was used. LWWA is potentially suitable for detecting environmental signal at the training set gradient ends, since it creates "local" datasets (cold lakes in the current case), which have weighted input in the reconstruction. The number of samples in "local" training set was set to 20 and the species data was $\log 10$ transformed. The model includes 191 sites and 132 taxa and has jackknife cross-validated coefficient of determination $\left(\mathrm{R}_{\text {Jack }}^{2}\right)$ of 0.91 , root mean squared error of prediction (RMSEP) of $0.88{ }^{\circ} \mathrm{C}(5.8 \%$ of the training set temperature gradient) and mean and maximum biases of 0.11 and $4.11^{\circ} \mathrm{C}$, respectively. Samplespecific modeling errors (estimated standard error of prediction $=\mathrm{eSEP}$ ) in the Revvatnet reconstruction (including all taxa) were determined using bootstrapping cross-validation with 999 iterations.

For comparison with the present reconstruction, we used the temperature data (June to August) published by D'Andrea et al. (2012), which is based on alkenone unsaturation in Lake Kongressvatnet located $\sim 100 \mathrm{~km}$ north from Revvatnet (Fig. 1a). The Kongressvatnet data were obtained from the World Data Center for Paleoclimatology and NOAA's National Climatic Data Center, Paleoclimatology Branch website (http://www.ncdc.noaa.gov/paleo/paleo.html). In addition, we compared the recent part (past $~ 100$ years) with available meteorological data from the Svalbard (Longyearbyen) airport ( 140 km north from Revvatnet) and from Bjørnøya ( 300 km south from Revvatnet). The mean annual air temperature data from Longyearbyen and the mean July air temperature data from Bjørnøya were available through the online database of the Norwegian Meteorological Institute (http://eklima.met.no/). The early part (1912-1920) of the 
Longyearbyen airport record was not used due to doubts on its reliability (Kohler et al., 2002). The temporally adjusted (closest years matched) records were statistically compared using Pearson correlation statistics.

Since the chironomid assemblage data had a linear (non-unimodal) response, the community shifts were assessed using a principal component analysis (PCA) with the program Canoco 5 (Šmilauer \& Lepš, 2014). The PC1 scores were compared with site-specific temperatures using Pearson Product-moment correlation coefficient $(R)$, corrected coefficient of determination $\left(R_{\text {adj }}^{2}\right)$ and the level of statistical significance $(p<0.05)$ to verify that the communities were responding to temperature. Using the modern analogue technique, the cut-level of the $2^{\text {nd }}$ percentile of all squared chi-squared distances in the modern calibration data was determined. These distances were then compared to the distance between each fossil assemblage and its most similar assemblage in the modern data set and used to define 'close' and 'no close' analogues. Fossil samples having values below the $2^{\text {nd }}$ percentile dissimilarity threshold were hence consider to have 'close' analogues in the calibration data, and consequently, ability to provide reliable temperature estimates. Segmented regression analysis was used to identify statistically significant breakpoint in the temperature reconstruction applying a minimum confidence level of $95 \%$. The selection of the best breakpoint and function type was based on maximizing the statistical coefficient of explanation, and performing tests of significance using the program SegReg (Oosterbaan, 2005).

To assess statistically significant trends in the reconstruction, the Mann-Kendall trend test (Gilbert, 1987) was used. In the non-parametric test for trend, the $S$-statistic is negative for a negative trend, zero for no trend and positive for an increasing trend. For a trend to have statistical significance, the $p$-value was required to be $<0.05$. To further depict general trends and stabilize chronological uncertainty and noise in the reconstructed values, LOESS smoother and the LOWESS (LOcally WEighted Scatterplot Smoothing) (Cleveland, 1979, 1981) algorithm was applied with a span 0.4. In illustrations of the breakpoint and trend analyses, temperature anomalies 
standardized to the record mean were used to exclude potential error originating from the fact that the study site locate close to the end of the training set temperature gradient (potential systematic overestimation of temperatures).

\section{Results}

The ${ }^{137} \mathrm{Cs}$ analysis of different cores from Revvatnet, showed a parallel peak at $\sim 5 \mathrm{~cm}$ for all three cores (RE1-3) from the southern basin (Fig. 2). The onset of Cs fallout from nuclear weapons testing in the early 1950s corresponds in RE2 for $6 \mathrm{~cm}$ (initial increase, assigned sample-specific year $1953 \mathrm{CE}$ according to linear age modeling) and the maximum fallout in $1963 \mathrm{CE}$ for $5 \mathrm{~cm}$ (maximum peak). A faster sedimentation rate was assigned for the northern basin (RE4), which receives melt waters from the glacier and has turbid water column, consequently leading to higher local sediment accumulation rate. Since the rate of sedimentation in the southern basin is consistently of similar magnitude and the ${ }^{137} \mathrm{Cs}$ peak is very distinct, it can be expected that no major and/or sudden changes in the rate of sediment deposition has occurred in this part of the basin. Chronological extrapolation provides an age estimate of $\sim 1720 \mathrm{CE}$ for the bottom core, but since the lower part of the sediment profile lacks chronological control, this estimate is uncertain. The rate of sedimentation in the basin is generally increased towards the present day (with lower rate of compaction), because of climate warming and increase in the catchment-derived material (Ojala et al. 2016; Luoto et al. 2019), so if anything, the extrapolated ages are more likely older than younger.

The Revvatnet RE2 sediment profile consisted of 14 taxa (Luoto et al., 2019), of which 10 most common ( $\geq 2$ occurrences) are shown in Fig. 3. All taxa were used in the temperature reconstruction. The most abundant chironomids in Revvatnet were Oliveridia tricornis (abundant between $~ 1720$ and 1980 CE), Micropsectra radialis-type (1720-1820 CE and 1920 CE-present) 
and Hydrobaenus lugubris-type (1780-1910 CE and 1960 CE-present). Orthocladius trigonolabistype, $O$. consobrinus-type and Metriocnemus eurynotus-type increased in the recent sediments. The primary PC axis 1 scores for chironomids in the Revvatnet record showed little changes (generally between -1 and 0 PCA units) from $1720 \mathrm{CE}$ until values began to increase from the $1940 \mathrm{CE}$ onward (Fig. 4). The highest values were reached between $1980 \mathrm{CE}$ and present ( 2-3 PCA units). The secondary PC axis 2 had highest values ( 1-2 PCA units) in the mid-stratigraphy (1830-1900 CE) and lowest values between 1720 and $1780 \mathrm{CE}$ and between 1920 and $1940 \mathrm{CE}$ (generally between -1 and -2 PCA units).

The chironomid-based mean July air temperature reconstruction resulted in values varying between $\sim 4$ and $8{ }^{\circ} \mathrm{C}$ (Fig. 4). During the $18^{\text {th }}$ century the temperatures remained at $4-5^{\circ} \mathrm{C}$. Between 1820 and $1920 \mathrm{CE}$, the values were slightly higher varying between $\sim 5$ and $6{ }^{\circ} \mathrm{C}$. According to the reconstruction, a colder period $\left(\sim 4{ }^{\circ} \mathrm{C}\right)$ prevailed in the 1920 s and 1930 s. Since then, the temperatures rapidly increased reaching $6{ }^{\circ} \mathrm{C}$ in the $1950 \mathrm{~s}, 7^{\circ} \mathrm{C}$ in the $1980 \mathrm{~s}$ and $8{ }^{\circ} \mathrm{C}$ in the 2000s. The inferred value for the surface sample is higher than the observed July average, however, it is within the general modern July temperature variability of 3 to $10{ }^{\circ} \mathrm{C}$ at the Hornsund station. The surface sample also has the highest sample-specific error, which is almost $2{ }^{\circ} \mathrm{C}$, while the other samples generally have errors below $1.5^{\circ} \mathrm{C}$ (Fig. 4). All samples had good modern analogues ( 2 percentile dissimilarity threshold $7.5 \mathrm{minDC}$ ), with the most similar communities in the early and most recent parts of the profile (3-5 minDC) (Fig. 4).

The temperature reconstruction correlated significantly with chironomid primary PC axis with $R$ of $0.82, R_{\text {adj }}^{2}$ of 0.65 and $p<0.001$. There was no significant correlation $(p=0.145)$ between inferred temperature and the secondary PC axis. When comparing the temperature reconstructions from Revvatnet and Kongressvatnet (Fig. 4), a significant correlation was found with $R$ of $0.56, R_{\text {adj }}^{2}$ of 0.29 and $p$ of 0.001 . Both records held a simultaneous initiation of temperature increasing trend from the 1940s onward. Based on the segmented regression analysis, a 
statistically significant $(p<0.05)$ optimal breakpoint in the Revvatnet temperature reconstruction was found at $1932 \mathrm{CE}$. In the regression function, there was a horizontal segment followed by sloping (Fig. 5). The Revvatnet mean July air temperature reconstruction also correlated with the 100-year observational mean annual air temperatures observed at the Longyearbyen airport $(R=$ $0.77, R_{\text {adj }}^{2}=0.56$ and $p$ of 0.003$)$ and the July temperatures observed in Bjørnøya $\left(R=0.87, R_{\text {adj }}^{2}=\right.$ 0.74 and $p$ of 0.001 ) (Fig. 6).

According to the Mann-Kendall trend test, there was a strong $(S=233, Z=4.1)$ and statistically significant $(p<0.001)$ increasing trend in the reconstructed values from Revvatnet (Fig. 7). Following this trend, the LOESS smoothed temperature anomalies (standardized to record mean) turned from negative to positive values in the 1930s. The most negative temperature anomaly (-1.3 $\left.{ }^{\circ} \mathrm{C}\right)$ occurred in the beginning and the most positive $\left(2.3^{\circ} \mathrm{C}\right)$ at the end of the sequence.

\section{Discussion}

Chironomid fauna of the Revvatnet sediment stratigraphy consisted of temperature sensitive taxa, such as the cold indicating Oliveridia tricornis, which was the most abundant chironomid and continuously present until the 1970s. Another cold-indicating chironomid in the calibration set, Micropsectra radialis-type, thrived during periods 1720-1820 CE and 1920 CE-present. Warmer indicating chironomids included Orthocladius trigonolabis-type, O. consobrinus-type and Metriocnemus eurynotus-type, which increased from the 1970s onward (Fig. 3). Although the latter taxa have been known to have preference for warmer lakes in northern Europe, they are also known to be more common in bird-impacted nutrient-enriched lakes of Svalbard (Brooks \& Birks, 2004; Luoto et al., 2014, 2015). Therefore, this study cannot fully separate the climate signal from the potential influence of increasing bird impact and nutrient enrichment in Revvatnet. However, the size and volume of Revvatnet is considerable compared to bird-impacted strand flat ponds reported 
by Brooks and Birks (2004) and Luoto et al. (2014, 2015), which is why the contribution of bird guano is probably a less important factor explaining the changes. Also, to confront this problem we compared the chironomid-inferred temperatures with observational temperature records

(meteorological validation of the reconstruction) in the more recent time interval when also these chironomid taxa that potentially favor bird impacted lakes appeared in the record.

Since the chironomid primary PC axis correlated strongly and significantly with the chironomid-based temperature reconstruction and there was no significant correlation with the secondary PC axis and inferred temperatures, the data suggests that chironomid assemblages in the Revvatnet sequence were responding to the reconstructed environmental variable (cf. de Jong et al., 2013). As all the fossil assemblages also had good modern analogues in the temperature calibration set (Fig. 4), we were subsequently able to "reliably" reconstruct past summer temperature variability from the Revvatnet core using chironomids. Compared to the temperature reconstruction from Kongressvatnet in western Svalbard (D’Andrea et al., 2012), a similar trend was found (Fig. 4). Although these two proxy-based reconstructions had statistically significant correlation, they also exhibited differences, which however, may be partly owing to the inaccuracy rising from the extrapolated lower part (below $7 \mathrm{~cm} /$ prior 1950s) of the Revvatnet record. Nonetheless, mismatch in ages would likely worsen the correlation between the two records rather than improve it.

The warmer temperatures within the LIA at Kongressvatnet between 1740-1770 CE were not as clearly present in the chironomid-based reconstruction at Revvatnet. Although it has been shown from elsewhere in Scandinavia that the LIA was not uniformly cold but often separated in two cold phases (Zawiska et al., 2017), it is also clear that it had marked spatial variability in timing and magnitude even between relatively adjacent sites (Tiljander et al., 2003; Rantala et al., 2016; Luoto et al., 2017a). Even today, the temperature varies considerably across the Svalbard High Arctic archipelago having an influence on permafrost and glacier activity (e.g. Humlum et al., 2003; Marsz \& Styszyńska, 2013). Martín-Moreno et al. (2017), for example, concluded that the 
influence of the LIA climate on glaciers was dissimilar in different parts of Svalbard depending on local climate but also glacier dynamics and surging. Pawłowska et al. (2016) revealed a sharp change in the sea-environmental conditions in central Hornsund at 1800 CE and their study on the ancient foraminiferal DNA (aDNA) revealed that the transition to the LIA between 1600 and 1800 CE was well marked by the increase in the percentage of monothalamous foraminifera aDNA sequences (mainly from genus Bathysiphon) and additionally by low sediment accumulation rate and low ice rafted debris (IRD) flux. This provided that the position of the glacier fronts was relatively distant to the fjord center, however, the fjord was influenced by the Arctic waters and melt waters (Pawłowska et al., 2016). Hence, the differences between lacustrine and marine records may result from the direct contact of fjord waters with developed tidal glaciers fronts.

Furthermore, the alkenone-based reconstruction from Kongressvatnet did not show as distinct temperature rise from the 1940s onward as the current chironomid-based reconstruction from Revvatnet. Curiously, the largest sample-specific errors in the chironomid-based reconstruction are in the more recent samples (Fig. 4) that could imply more uncertain temperature estimations. Nonetheless, there are close modern analogues in the training set for the samples in the later part of the core suggesting that the reconstruction does not become less reliable. As the best way to determine reliability of a temperature reconstruction is to compare the inferred values against instrumentally observed values over the observational period (Larocque-Tobler et al., 2015), we tested the Revvatnet reconstruction against available mean July meteorological temperatures from Bjørnøya and annual meteorological temperatures from Longyearbyen (Fig. 6). In addition to statistically significant correlation between the Revvatnet temperatures and the observational records, we also found that the summer time records were similar in their magnitude of recent change suggesting that the current reconstruction is reliable also in the most recent sediment section. 
Similar to the hydroclimatic appearance of the LIA (Helama et al., 2017; Linderholm et al., 2018), there is distinct spatial variability in the onset of the MW in northern Scandinavia (Weckström et al., 2006; Matskovsky \& Helama, 2014; Luoto \& Nevalainen, 2017). The segmented regression analysis of the Revvatnet reconstruction showed a horizontal segment followed by sloping with the statistically significant breakpoint at $1932 \mathrm{CE}$ (Fig. 5), hence indicating that a climate warming threshold occurred in the 1930s. A similar climate warming development of the past century has been meteorologically observed from Bjørnøya, $300 \mathrm{~km}$ south of Revvatnet (Fig. 6). Similarly between the inferred and observed mean July air temperature records, the temperatures rapidly increased in the 1930s and 1940s but stabilized to only a slight warming from the 1950s until a new distinct temperature increase during the most recent decades. The annual mean air temperature observations from Longyearbyen airport, $140 \mathrm{~km}$ north of Lake Revvatnet, show partly differing story with temperatures remaining constantly low during the past century until a slow progressive increase in the 1960s followed by rapidly increasing trend during the most recent decades, which is similar to the Revvatnet and Bjørnøya summer temperature records (Fig. 6). The differences between mean July and mean annual temperature records suggest significant variability between seasonal temperature trends in Svalbard. In previous paleoclimatic studies from Lake Svartvatnet, located $15 \mathrm{~km}$ south of Lake Revvatnet, it has been shown that in centennial-scale chironomid-based mean July air temperature and stable oxygen isotope-based mean annual air temperature reconstructions the general trends are similar but significant differences occur in the magnitude of climate changes (Arppe et al., 2017; Luoto et al., 2018). These studies, however, were conducted with significantly lower resolution for the last centennial than in the present study, but for example, the late Holocene cooling trend (cf. Wanner et al., 2008) was less pronounced in the annual record, while the annual record demonstrated a much more prominent LIA signal together with emphasized MW compared to the summer temperature record. Therefore, the present findings well agree with the previous evidence on that summer and annual temperature trends have similar 
general trends, but also significant differences in magnitude and timing, highlighting the significance of seasonal climatic components in the High Arctic.

According to meteorological observations in Hornsund, the summer air temperatures have increased $2{ }^{\circ} \mathrm{C}$ since the beginning of instrumental measurements in 1979 (Marsz \& Styszyńska, 2013). This agrees well with our present reconstruction, which shows an increase from $6.3{ }^{\circ} \mathrm{C}$ in the mid-1970s to the present $8.3{ }^{\circ} \mathrm{C}$ (Fig. 4). The $\sim 2{ }^{\circ} \mathrm{C}$ rise also concurs with the Bjørnøya observational record of mean July air temperatures, whereas in the observed annual temperatures from Longyearbyen there is an over $3{ }^{\circ} \mathrm{C}$ temperature increase since the $1980 \mathrm{~s}$. Therefore, it appears clear that winter warming is even greater than summertime warming in Svalbard. For Svalbard, climate projections also suggest greater temperature increase in the future during winter than summer (Førland et al., 2011).

A paleoclimate synthesis of Arctic-wide mean summer temperatures have shown that the Arctic cooling trend, which was culminated during the LIA, was reversed during the $20^{\text {th }}$ century, with warmest decades occurring between 1950 and 2000 CE (Kaufman et al. 2009). The present results from Revvatnet are in agreement with these pan-Arctic temperature anomalies (Fig. 7). The current sediment record extends back in time to the early $18^{\text {th }}$ century, when the LIA was still at its coldest in northern Europe (Osborn \& Briffa, 2006; Zawiska et al., 2017). Compared to the modern temperature inferred from the topmost sediment sample, the coldest temperatures inferred in the $18^{\text {th }}$ century were $4.3{ }^{\circ} \mathrm{C}$ lower (Fig. 7). This difference between the present and LIA temperatures is hence considerably larger than the $2{ }^{\circ} \mathrm{C}$ difference estimated from boreal northern Europe (Luoto, 2013) but at similar magnitude as in the north-eastern European Russian Arctic (5 ${ }^{\circ} \mathrm{C}$ ) (Luoto et al. 2017b), underlining the influence of Arctic climate amplification. Our data shows a statistically significant temperature increasing trend from the LIA towards the present with more stable 100-year period between 1820 and 1920 CE (Fig. 7), probably reflecting the time phase between the LIA and the MW that was characterized by reduced variability in the North Atlantic 
Oscillation index (Trouet et al., 2009; Luoto \& Nevalainen, 2018). According to the breakpoint analysis (Fig. 6) and LOESS trend (Fig. 7), a climate warming threshold in the 1930s was assigned. The temperature increase from the 1720 to $1820 \mathrm{CE}$ was relatively rapid, approximately $0.2{ }^{\circ} \mathrm{C}$ per decade, but the temperature increase from the 1930s until present clearly exceeds this being approximately $0.5^{\circ} \mathrm{C}$ per decade (Fig. 7). Previously, the temperature increase from the 1960 s to $2050 \mathrm{CE}$ has been projected to be $0.3{ }^{\circ} \mathrm{C}$ per decade (Hanssen-Bauer, 2002), which is slightly lower than suggested for the period from $1960 \mathrm{CE}$ to present day by the current reconstruction. In these temperature comparisons it should be noted though that the used temperature calibration model has an RMSEP of $0.88{ }^{\circ} \mathrm{C}$ and the sample-specific errors vary between 1.1 and $2.0^{\circ} \mathrm{C}$. While these uncertainties are seemingly large compared to the late Holocene climate oscillations, it is likely that potential errors deriving from the chironomid-based temperature estimates are systematic between the focal samples throughout the profile considering that temperature is the dominant community forcer and secondary environmental factors do not play a significant role (Heiri et al. 2003; Brooks 2006). Moreover, the RMSEP of the model used in this study is much lower than reported from other existing chironomid-based temperature transfer functions, such as the widely used Swiss, Norwegian and their combined version with RMSEPs of 1.3-2.6 ${ }^{\circ} \mathrm{C}$ (Heiri et al., 2011). Therefore, the results of this study well manifests the exceptional speed and scale of the ongoing climate warming in southern Svalbard and provides an important perspective for estimations of the present and future Arctic environmental change.

\section{Conclusions}

The present 300-year-long reconstruction of mean July air temperature from Revvatnet showed significant correlation with a previous paleolimnological reconstruction from Kongressvatnet, 100 $\mathrm{km}$ north from our study site, however, with more distinct recent warming. The Revvatnet 
paleotemperature record also correlated significantly with the meteorological mean July temperatures from Bjørnøya over the observational period (100 years) showing close correspondence. Compared to instrumental temperatures from Svalbard Airport ( $140 \mathrm{~km}$ north), the initiation of rapidly increased temperatures occurred earlier in the summer temperature records than in the annual temperature record. According to the breakpoint analysis, a climate warming threshold occurred in the summer temperatures in the 1930s. We also found that the climate warming trend was progressive and statistically significant. Since the LIA, the summer temperatures have increased by $>4{ }^{\circ} \mathrm{C}$ being far greater warming than in continental Scandinavia. Following the breakpoint in temperature increase in the 1930s, the warming rate has been as much as $0.5{ }^{\circ} \mathrm{C}$ per decade. These findings hence emphasize the influence of Arctic amplification and significance of seasonal climate components and suggest climate warming that is exceptional in its magnitude. The scale of temperature change over the past century proposes cascading environmental impacts in this climatically ultrasensitive region, where significant environmental and ecological shifts have already been observed.

\section{Acknowledgements}

We are grateful to Laura Arppe, Mimmi Oksman, Mateusz Damrat, Joanna Pawłowska and the crew of the Polish Polar Station Hornsund for their help with the fieldwork. Constructive comments by two journal reviewers are greatly appreciated.

\section{Financial support}

This work was supported by the Emil Aaltonen Foundation (T.P.L., grants numbers 160156, 170161,180151); Kone Foundation (T.P.L., grant number 090140); Academy of Finland (A.E.K.O., 
400

401

402

403

404

405

406

407

408

409

410

411

412

413

414

415

416

417

418

419

420

421 in response to environmental change during the past 700 years on Svalbard. Journal of

422 Paleolimnology, 31, 483-498.

Arppe, L., Kurki, E., Wooller, M. J., Luoto, T. P., Zajączkowski, M., \& Ojala, A. E. K. (2017). A 5500-year oxygen isotope record of high-arctic environmental change from southern Spitsbergen. The Holocene, 27, 1948-1962.

Axford, Y., Briner, J. P., Miller, G. H., \& Francis, D. R. (2009). Paleoecological evidence for abrupt cold reversals during peak Holocene warmth on Baffin Island, Arctic Canada. Quaternary Research, 71, 142-149.

Besonen, M. R., Patridge, W., Bradley, R. S., Francus, P., Stoner, J. S., \& Abbott, M. B. (2008). A record of climate over the last millennium based on varved lake sediments from the Canadian High Arctic. The Holocene, 18, 169-180.

Brooks, S.J. (2006). Fossil midges (Diptera: Chironomidae) as palaeoclimatic indicators for the Eurasian region. Quaternary Science Reviews, 25, 1894-1910. 
Brooks, S. J., Langdon, P. G., Heiri, O. (2007). The identification and use of Palaearctic

Chironomidae larvae in palaeoecology. Quaternary Research Association, London.

Chapin, F. S., Sturm, M., Serreze, M. C., McFadden, J. P., Key, J. R., Lloyd, A. H., ... Beringer, J. (2005). Role of land-surface changes in Arctic summer warming. Science, 310, 657-660.

Cisek, M., Makuch, P., \& Petelski, T. (2017). Comparison of meteorological conditions in Svalbard fjords: Hornsund and Kongsfjorden. Oceanologia, 59, 413-421.

Cleveland, W. S. (1979). Robust locally weighted fitting and smoothing scatterplots. Journal of the American Statistical Association, 74, 829-836.

Cleveland, W. S. (1981). A program for smoothing scatterplots by robust locally weighted fitting. The American Statistician, 35, 54.

D’Andrea, W. J., Vaillencourt, D. A., Balascio, N. L., Werner, A., Roof, S. R., Retelle, M., \& Bradley, R. S. (2012). Mild Little Ice Age and unprecedented recent warmth in an 1800 year lake sediment record from Svalbard. Geology, 40, 1007-1010.

de Jong, R., Kamenik, C., Westover, K., \& Grosjean, M. (2013). A chrysophyte stomatocyst-based reconstruction of cold-season air temperature from Alpine Lake Silvaplana (AD 1500-2003); methods and concepts for quantitative inferences. Journal of Paleolimnology, 50, 519-533.

Eggermont, H., \& Heiri, O. (2012) The chironomid-temperature relationship: expression in nature and palaeoenvironmental implications. Biological Reviews, 87, 430-456. 
450 Engels, S., Self, A. E., Luoto, T. P., Brooks, S. J., \& Helmens, K. F. (2014). A comparison of three 451 Eurasian chironomid-climate calibration datasets on a W-E continentality gradient and the 452 implications for quantitative temperature reconstructions. Journal of Paleolimnology, 51, 529-547. 453

454 Fortin, M. C., Medeiros, A. S., Gajewski, K., Barley, E. M., Larocque-Tobler, I., Porinchu, D. F., \& 455 Wilson, S. E. (2015). Chironomid-environment relations in northern North America. Journal of 456 Paleolimnology, 54, 223-237.

457

458 Førland, E. J., Benestad, R., Hanssen-Bauer, I., Haugen, J. E., \& Skaugen, T. E. (2011).

459 Temperature and precipitation development at Svalbard 1900-2100. Advances in Meteorology, 460 https://doi.org/10.1155/2011/893790.

461

462

Gilbert, R. O. (1987). Statistical methods for environmental pollution monitoring. Van Nostrand 463 Reinhold, New York.

464

465

466

Hanssen-Bauer, I. (2002). Temperature and precipitation in Svalbard 1912-2050: measurements and scenarios. Polar Record, 38, 225-232.

467

Palaeogeography, Palaeoclimatology, Palaeoecology, 199, 95-106.

471

Helama, S., Luoto, T.P., Nevalainen, L., \& Edvardsson, J. (2017). Rereading a tree-ring database to 473 illustrate depositional histories of subfossil trees. Palaeontologia Electronica, 20.1.2A, 1-12. 
475 Hofmann, W. (1988). The significance of chironomid analysis (Insecta: Diptera) for

Humlum, O., Instanes, A., \& Sollid, J.L. (2003). Permafrost in Svalbard: A review of research 1997. Geografiska Annaler: Series A, Physical Geography, 87, 203-214.

Kaufman, D. S. (2009). An overview of late Holocene climate and environmental change inferred from Arctic lake sediment. Journal of Paleolimnology, 41, 1-6. Science, 325, 1236-1239. regional water isotopes. Quaternary Science Reviews, 131, 274-284. funded project. Norwegian Polar Institute, Oslo, Norway. 
500 Martín-Moreno, R., Allendo Álvarez, F., \& Ove Hagen, J. (2017). 'Little Ice Age’ glacier extent 501 and subsequent retreat in Svalbard archipelago. The Holocene, 27, 1379-1390.

502

503 Larocque-Tobler, I., Filipiak, J., Tylmann, W., Bonk, A., \& Grosjean, M. (2015). Comparison 504 between chironomid-inferred mean-August temperature from varved Lake Żabińskie (Poland) and 505 instrumental data since 1896 AD. Quaternary Science Reviews, 111, 35-50.

506

507 Lecavalier, B. S., Fisher, D. A., Milne, G. A., Vinther, B. M., Tarasov, L., Huybrechts, P., ... Dyke, 508 A. S. (2017). High Arctic Holocene temperature record from the Agassiz ice cap and Greenland ice 509 sheet evolution. Proceedings of the National Academy of Sciences, 114, 5952-5957.

510

511 Linderholm, H. W., Nicolle, M., Francus, P., Gajewski, K., Helama, S., Korhola, A., ... Väliranta, 512 M. (2018). Arctic hydroclimate variability during the last 2000 years: current understanding and 513 research challenges. Climate of the Past, 14, 473-514.

515 Lund, D. C., Lynch-Stieglitz, J., \& Curry, W. B. (2006). Gulf Stream density structure and transport 516 during the past millennium. Nature, 444, 601-604.

517

518 Luoto, T. P. (2013). How cold was the Little Ice Age? A proxy-based reconstruction from Finland 519 applying modern analogues of fossil midge assemblages. Environmental Earth Sciences, 68, 13215201329. 
Luoto, T. P. (2009). Subfossil Chironomidae (Insecta: Diptera) along a latitudinal gradient in Finland: development of a new temperature inference model. Journal of Quaternary Science, 24, $150-158$.

Luoto, T. P., \& Nevalainen, L. (2018). Temperature-precipitation relationship of the Common Era in northern Europe. Theoretical and Applied Climatology, 132, 933-938.

Luoto, T. P., \& Nevalainen, L. (2017). Quantifying climate changes of the Common Era for Finland. Climate Dynamics, 49, 2557-2567.

Luoto, T. P., \& Ojala, A. E. K. (2017). Meteorological validation of chironomids as a paleotemperature proxy using varved lake sediments. The Holocene, 27, 870-878.

Luoto, T. P., Rantala, M. V., Kivilä, E. H., Nevalainen, L., \& Ojala, A. E. K. (2019).

Biogeochemical cycling and ecological thresholds in a High Arctic lake (Svalbard). Aquatic Sciences, 81, 34 .

Luoto, T. P., Kivilä, E. H., Rantala, M. V., \& Nevalainen, L. (2017a). Characterization of the Medieval Climate Anomaly, Little Ice Age and recent warming in northern Lapland. International Journal of Climatology, 37, 1257-1266.

Luoto, T. P., Kuhry, P., Holzkämper, S., Solovieva, N., \& Self, A.E. (2017). A 2000-year record of lake ontogeny and climate variability from the north-eastern European Russian Arctic. The Holocene, 27, 339-348. 
Luoto, T. P., Rantala, M. V., Galkin, A., Rautio, M., \& Nevalainen, L. (2016). Environmental determinants of chironomid communities in remote northern lakes across the treeline - Implications for climate change assessments. Ecological Indicators, 61, 991-999.

Luoto, T. P., Oksman, M., \& Ojala, A. E. K. (2015). Climate change and bird impact as drivers of High Arctic pond deterioration. Polar Biology, 38, 357-368.

Luoto, T.P., Kaukolehto, M., Weckström, J., Korhola, A., \& Väliranta, M. (2014). New evidence of warm early-Holocene summers in subarctic Finland based on an enhanced regional chironomidbased temperature calibration model. Quaternary Research, 81, 50-62.

Luoto, T. P., Brooks, S. J., \& Salonen, V. P. (2014). Ecological responses to climate change in a bird-impacted High Arctic pond (Nordaustlandet, Svalbard). Journal of Paleolimnology, 51, 87-97.

Majewski, W., Szczuciński, W., \& Zajączkowski, M. (2009). Interactions of Arctic and Atlantic water-masses and associated environmental changes during the last millennium, Hornsund (SW Svalbard). Boreas, 38, 529-544.

Marsz, A. A., \& Styszyńska, A. (eds). (2013). Climate and climate change at Hornsund, Svalbard. Gdynia Maritime University, Gdynia, 402 pp.

Matskovsky, V. V., \& Helama, S. (2014). Testing long-term summer temperature reconstruction based on maximum density chronologies obtained by reanalysis of tree-ring data sets from northernmost Sweden and Finland. Climate of the Past, 10, 1473-1487. 
572 Nazarova, L., Bleibtreu, A., Hoff, U., Dirksen, V., \& Diekmann, B. (2017). Changes in temperature 573 and water depth of a small mountain lake during the past 3000 years in Central Kamchatka reflected 574 by a chironomid record. Quaternary International, 447, 46-58.

575

576 Nazarova, L., Self, A. E., Brooks, S. J., van Hardenbroek, M., Herzschuh, U., \& Diekmann, B. 577 (2015). Northern Russian chironomid-based modern summer temperature data set and inference 578 models. Global and Planetary Change, 134, 10-25.

579

580 Nilsen, F., Skogseth, R., Vaardal-Lunde, J., \& Inall, M. (2016). A Simple Shelf Circulation Model: 581 Intrusion of Atlantic Water on the West Spitsbergen Shelf. Journal of Physical Oceanography, 46, $582 \quad 1209-1230$.

583

584 Nordli, Ø. (2010). The Svalbard airport temperature series. Bulletin of Geography. Physical 585 Geography Series, 3, 5-25.

Ojala, A. E. K., Arppe, L., Luoto, T. P., Wacker, L., Kurki, E., Zajączkowski, M., ... Oksman, M. 588 (2016). Sedimentary environment, lithostratigraphy and dating of sediment sequences from Arctic 589 lakes Revvatnet and Svartvatnet in Hornsund, Svalbard. Polish Polar Research, 37, 23-48.

Oosterbaan, R. (2005). Statistical significance of segmented linear regression with breakpoint using variance analysis and F-tests. URL https://www.waterlog.info/segreg.htm.

594 Osborn, T. J., \& Briffa, K. R. (2006). The spatial extent of 20th-century warmth in the context of 595 the past 1200 years. Science, 311, 841-844. 
600

601

602

603

604

605

606

607

608

609

610

611

612

613

614

615

616

617

618

619

Pawłowska, J., Zajączkowski, M., Łącka, M., Lejzerowicz, F., Esling, P., \& Pawłowski, J. (2016).

Palaeoceanographic changes in Hornsund Fjord (Spitsbergen, Svalbard) over the last millennium: new insights from ancient DNA. Climate of the Past, 12, 1459-1472.

Plikk, A., Engels, S., Luoto, T. P., Nazarova, L., Salonen, J. S., \& Helmens, K. F. (2019).

Chironomid-based temperature reconstruction for the Eemian Interglacial (MIS 5e) at Sokli, northeast Finland. Journal of Paleolimnology, 61, 355-371.

Rantala, M. V., Luoto, T. P., \& Nevalainen, L. (2016). Temperature controls organic carbon sequestration in a subarctic lake. Scientific Reports, 6, 34780.

Self, A. E., Brooks, S. J., Birks, H. J. B., Nazarova, L., Porinchu, D., Odland, A., Yang, Y. H., \& Jones, V.J. (2011). The distribution and abundance of chironomids in high-latitude Eurasian lakes with respect to temperature and continentality: development and application of new chironomidbased climate-inference models in northern Russia. Quaternary Science Reviews, 30, 1122-1141.

Shala, S., Helmens, K. F., Luoto, T. P., Salonen, J. S., Väliranta, M., \& Weckström, J. (2017). Comparison of quantitative Holocene temperature reconstructions using multiple proxies from a northern boreal lake. The Holocene, 27, 1745-1755.

17 Šmilauer, P., \& Lepš, J. (2014). Multivariate Analysis of Ecological Data Using CANOCO 5. 18 Cambridge University Press. 
643 Werner, J.P., Divine, D.V., Ljungqvist, F.C., Nilsen, T., \& Francus, P. (2018). Spatio-temporal

Thomas, E. K., Axford, Y., \& Briner, J. P. (2008). Rapid 20th century environmental change on northeastern Baffin Island, Arctic Canada inferred from a multi-proxy lacustrine record. Journal of Paleolimnology, 40, 507-517.

Tiljander, M., Saarnisto, M., Ojala, A. E. K., \& Saarinen, T. (2003). A 3000-year palaeoenvironmental record from annually laminated sediments of Lake Korttajärvi, central Finland. Boreas, 32, 233-243.

Trouet, V., Esper, J., Graham, N. E., Baker, A., Scourse, J. D., \& Frank, D. C. (2009). Persistent positive North Atlantic Oscillation mode dominated the Medieval climate anomaly. Science, 324, $78-80$.

Wanamaker Jr, A. D., Butler, P. G., Scourse, J. D., Heinemeier, J., Eiríksson, J., Knudsen, K. L., \& Richardson, C. A. (2012). Surface changes in the North Atlantic meridional overturning circulation during the last millennium, Nature Communications, 3, 899.

Wanner, H., Beer, J., Bütikofer, J., Crowley, T. J., Cubasch, U., Flückiger, J., ... Küttel, M. (2008). Mid-to Late Holocene climate change: an overview. Quaternary Science Reviews, 27, 1791-1828.

Weckström, J., Korhola, A., Erästö, P., \& Holmström, L. (2006). Temperature patterns over the past eight centuries in Northern Fennoscandia inferred from sedimentary diatoms. Quaternary Research, $66,78-86$. variability of Arctic summer temperatures over the past 2 millennia. Climate of the Past, 14, 527. 
646 Zawiska, I., Luoto, T. P., Nevalainen, L., Tylmann, W., Jensen, T.C., Obremska, M., Słowiński, M., 647 Woszczyk, M., Schartau, A. K., \& Walseng, B. (2017). Climate variability and lake ecosystem 648 responses in western Scandinavia (Norway) during the last Millennium. Palaeogeography,

649 Palaeoclimatology, Palaeoecology, 466, 231-239.

650

651

652

653

654

655

656

657

658

659

660

661

662

663

664

665

666

667

668

669 
672 Table 1. Characteristics of the used chironomid-based calibration set consisting of boreal, subarctic 673 and Arctic lakes.

Mean July air temperature gradient $\left({ }^{\circ} \mathrm{C}\right)$

Total number of sites

Barren tundra sites

Mountain birch woodland sites

Pine and birch forest sites

Spruce, pine, and birch forest sites

Number of taxa

Calibration technique

Number of samples in "local" training set

Coefficient of determination $\left(\mathrm{R}_{\text {Jack }}^{2}\right)$

Root mean squared error of prediction, RMSEP

Mean modeling bias $15.3^{\circ} \mathrm{C}\left(17.1-1.8^{\circ} \mathrm{C}\right)$

191

42

47

38

64

132

Locally weighted-weighted averaging (LWWA)

20

0.91

$0.88{ }^{\circ} \mathrm{C}$

$0.11{ }^{\circ} \mathrm{C}\left(0.00-4.11{ }^{\circ} \mathrm{C}\right)$ 
683

684

685

686

687

688

689

690

691

692

693

694

695

696

697

698

699

700

701

702

703

704

705

706

\section{Figure captions}

Fig. 1 Location of the study site Revvatnet in southwestern Svalbard (a) together with lake bathymetry (b).

Fig. $2{ }^{137} \mathrm{Cs}$ activity in the sediment cores RE1-4. The ${ }^{137} \mathrm{Cs}$ peak refers to the nuclear weapons testing maximum fallout in 1963 CE. Core RE2 was used in the chironomid analysis.

Fig. 3 Chironomid biostratigraphy of the 10 most common taxa ( $\geq 2$ occurrences) from Revvatnet (Svalbard). The assemblage compositions are expressed as relative abundance of total chironomids. Full chironomid assemblage composition is published elsewhere (Luoto et al., 2019). Also the rare taxa missing from the figure were included in the temperature reconstruction.

Fig. 4 Principal component analysis (PCA) axis scores for chironomids, chironomid-based mean July air temperature reconstruction, sample-specific prediction errors estimated using bootstrapping cross-validation and closest modern analogues in the sediment record from Revvatnet, southwestern Svalbard. Also shown are the alkenone-based temperature reconstruction from Kongressvatnet, western Svalbard (D’Andrea et al., 2012), the model's prediction error (root mean squared error of prediction, RMSEP) and the 2 percentile modern analogue dissimilarity threshold.

Fig. 5 Optimal breakpoint at $1932 \mathrm{CE}$ in the chironomid-inferred temperature reconstruction (gray dots) from Revvatnet (Svalbard) assessed using segmented regression analysis. Shown are the 95\% confidence block of the optimal breakpoint and the $95 \%$ confidence belt. 
707 Fig. 6 Chironomid-inferred mean July air temperature reconstruction (blue) with sample-specific 708 errors from Revvatnet (Svalbard) compared with mean annual meteorological observations (red) 709 from Svalbard Airport (Longyearbyen) and mean July air temperature observations (green) from 710 Bjørnøya over the instrumental period (past $~ 100$ years).

712 Fig. 7 Reconstructed summer temperature anomalies (white dots) from the Revvatnet (western 713 Svalbard) sediment record using fossil chironomids and the transfer function approach. According 714 to the Mann-Kendall trend test, there is a statistically significant increasing trend in the samples. To 715 stabilize chronological uncertainty and noise in the reconstructed values, a LOESS smooth was used 716 (blue/red curve). Also shown are the sample-specific errors (eSEP) estimated using bootstrapping 717 cross-validation (dashed lines). 